\title{
Blødningsrisiko ved bruk av nye antikoagulantia
}

\author{
Risikoen for gastrointestinal blødning ved bruk av de nye antikoagula- \\ sjonsmidlene dabigatran og rivaroksaban er omtrent som ved bruk av \\ warfarin. Dette viser to amerikanske studier.
}

En av fordelene ved de nye perorale antikogulasjonsmidlene er at de kan gis i fast dose uten at det er behov for monitorering av koagulasjonseffekten. Det er nylig publisert to amerikanske kohortstudier der blødningsrisikoen ved bruk av dabigatran og rivaroksa-

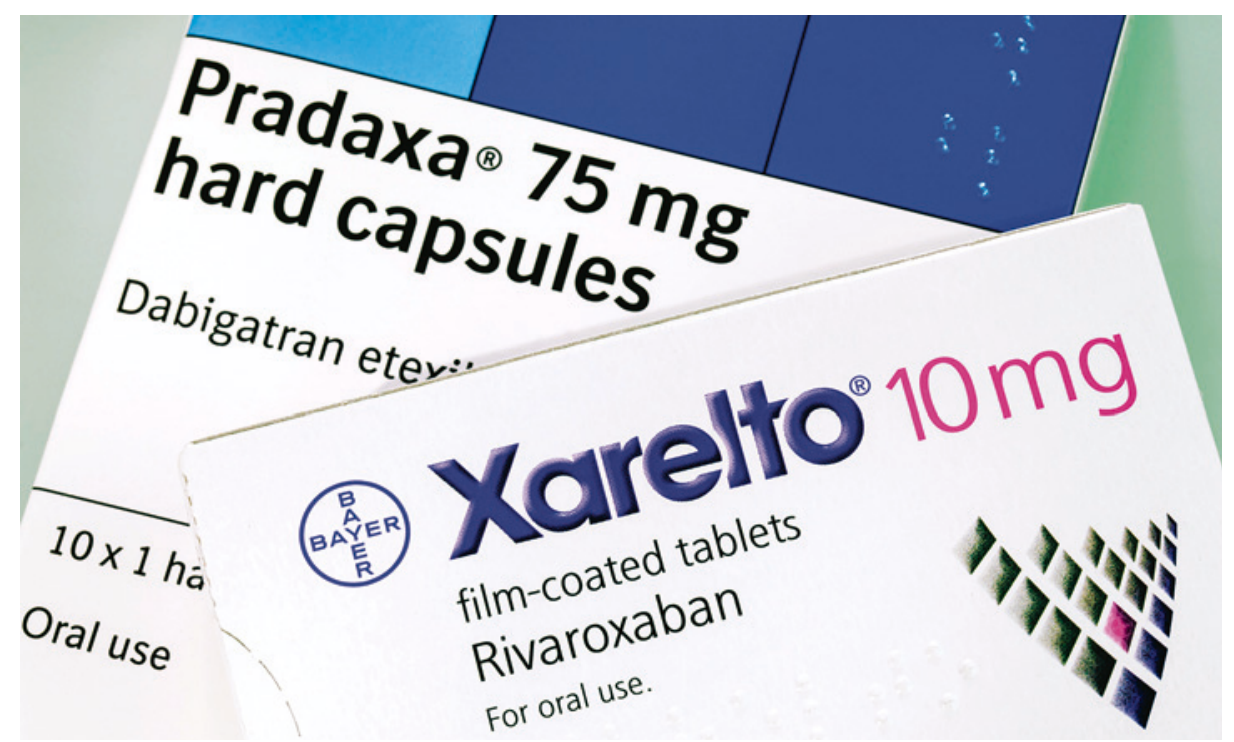

Illustrasjonsfoto: Science Photo Library ban er sammenliknet med risikoen ved bruk av warfarin i vanlig klinisk praksis $(1,2)$.

Etter justering for konfunderende faktorer var det ingen sikker forskjell i blødningsrisiko ved bruk av dabigatran og rivaroksaban sammenliknet med warfarin i noen av studiene. Imidlertid var det økt blødningsrisiko hos pasienter over 65 år og særlig hos dem over 75 år.

- Resultatene fra disse to godt utførte studiene bekrefter langt på vei eksisterende kunnskap om blødningsrisiko fra randomiserte, kontrollerte effektstudier, sier overlege Per Olav Vandvik ved Medisinsk avdeling, Sykehuset Innlandet, Gjøvik. - Årlig risiko for alvorlige blødninger ligger på rundt $2-3 \%$. De nye antikoagulasjonsmidlene synes å gi noe økt risiko for gastrointestinale blødninger, spesielt hos eldre og hos dem med lav kroppsvekt, sier han.

- Studier på dette området kan være vanskelige å tolke, blant annet på grunn av usikkerhet omkring utgangsrisikoen for blødninger, subgruppeanalyser med tvilsom reliabilitet eller manglende statistisk styrke, noe som også gjelder disse to studiene. Sannsynligvis vil Norsk selskap for trombose og hemostase snart komme med endringer $\mathrm{i}$ sine anbefalinger, sier Vandvik.

Trine B. Haugen

Tidsskriftet

Litteratur

1. Abraham NS, Singh S, Alexander GC et al. Comparative risk of gastrointestinal bleeding with dabigatran, rivaroxaban, and warfarin: population based cohort study. BMJ 2015; 350: h1857.

2. Chang H-Y, Zhou M, Tang $W$ et al. Risk of gastrointestinal bleeding associated with oral anticoagulants: population based retrospective cohort study. BMJ 2015; 350: h1585.

\section{Kan epilepsi kontrolleres metabolsk?}

\section{Epileptiske anfall hos mus kan kuperes med laktatdehydrogen- asehemmere.}

Antiepileptika virker på nevronenes ionekanaler eller på reseptorer for nevrotransmittere, men har dårlig effekt hos om lag en tredel av pasientene. Det er vist at for noen kan en ketogen diett hjelpe. Dette har vært bakgrunnen for å undersøke om epilepsianfall kan reduseres ved å hemme enzymet laktatdehydrogenase (LDH) hos mus (1).

LDH-hemming ved bruk av oksamat $i$ en musehjerneskive in vitro reduserte laktatdanningen i nevronene, hyperpolariserte dem og gjorde dem mindre eksitable. Applikasjon av laktat i nevronene affiserte ikke membranpotensialet, men pyruvat, som er nedstrøms for hemmet laktatdehydrogenase, opphevet hyperpolariseringen og gjorde nevronene normalt eksitable. Applikasjon av oksamat i astrocytten i et nevron-astrocytt-par hemmet skytteltrafikken av laktat over til nevronet og hyperpolariserte nevronet. LDH-hemming undertrykte også anfallstendensen i en musemodell. Av 20 ulike antiepileptika som ble brukt i studien, var det ett, nemlig stiripentol, som hemmet laktatdehydrogenase. Et derivat av stiripentol, isosafrol, virket enda bedre.

- Dette er en spennende studie, sier Karl Otto Nakken, som er overlege ved Spesialsykehuset for epilepsi i Sandvika. - Man har lenge spekulert på om terapiresistent epilepsi blant annet kan skyldes metabolske forstyrrelser i en nevronpopulasjon. Ved vårt sykehus tilbyr vi en ketogen eller modifisert ketogen diett til både barn og voksne med vanskelig kontrollerbar epilepsi. Særlig god effekt av slik diett har pasientgrupper med kjente metabolske encefalopatier, nemlig dem med glukosetransportprotein 1-mangel (GLUT1-deficiency syndrome) og pyruvatdehydrogenasemangel (PDHD), sier han.

- Jeg var ikke kjent med at stiripentol virket anfallsdempende via LDH-hemming. Stiripentol er et «smalt» antiepileptikum som særlig benyttes hos barn med en sjelden og svært terapiresistent myoklonusepilepsi (Dravets syndrom). Kanskje bør derivatet isosafrol bli gjenstand for kliniske utprøvninger, sier Nakken.

\section{Haakon B. Benestad}

Universitetet i Oslo

\section{Litteratur}

1. Sada N, Lee S, Katsu T et al. Epilepsy treatment. Targeting LDH enzymes with a stiripentol analog to treat epilepsy. Science 2015; 347: 1362-7. 